\begin{tabular}{|c|c|c|}
\hline 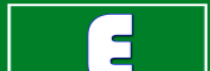 & International Journal of Current Research in & \\
\hline & Biosciences and Plant Biology & \\
\hline $\begin{array}{l}\text { EX } \\
\text { PUBL }\end{array}$ & $\begin{array}{c}\text { ISSN: 2349-8080 (Online) • Volume } 3 \bullet \text { Number } 3 \text { (March-2016) } \\
\text { Journal homepage: www.ijcrbp.com }\end{array}$ & \\
\hline
\end{tabular}

\title{
Corroborated Economic Viability of Acridity Free Elephant Foot Yam Introduction with Spice Intercropping under Sloppy Foot Hills of Imphal-East
}

\author{
Ravi Kiran Thirumdasu ${ }^{*}$, A.K. Bijaya Devi² and Momoko Thokchom \\ ${ }^{1}$ Department of Vegetable and Spice Crops, Uttar Banga Krishi Viswavidyalaya, Pundibari, Cooch Behar, West Bengal, India \\ ${ }^{2}$ Department of Horticulture, College of Agriculture, Central Agricultural University, \\ Imphal - 795004, Manipur, India \\ *Corresponding author.
}

\begin{abstract}
A b s tract
Initial study was conducted on acridity free elephant foot yam (Amorphophallus campanulatus Roxb. Blume) cv. Gajendra intercropping with spice crops (ginger and turmeric) under sloppy foot hills of Imphal-East, Manipur for economic viability. Elephant foot yam $\left(13.02 \mathrm{tha}^{-1}\right)$, turmeric $\left(42.84 \mathrm{t} \mathrm{ha}^{-1}\right)$ and ginger $\left(36.51 \mathrm{t} \mathrm{ha}^{-1}\right)$ were recorded highest yield as sole crops. Among the intercropped treatments maximum income per rupee investment (4.07), monetary equivalent ratio (0.78) and per day returns (2535.83 $\mathrm{Rs} \mathrm{ha}^{-1}$ ) was recorded in elephant foot yam intercropped with double row of turmeric. The result indicating that among the intercropping treatments, elephant foot yam cv. Gajendra with double row of turmeric would be appropriate to harvest nonacridity corms for nutritional security coupled with profitable returns from turmeric under sloppy foot hills of Imphal-East.
\end{abstract}

\section{Introduction}

In North-East India, most of the tribal depend on agriculture for livelihood. But the areas like sloppy foot hills of Imphal-East, Manipur throws a challenge for tribal farmers. They mostly restricted to cultivate in small holdings under rain-fed condition. In such limited land resources, profits can be aided through elevating the productivity by intercropping over traditional cropping system. Salter (1986) also indicated that simultaneous growing of two or more crops not only gives more yield and net profit but it also cuts the cost of cultivation. Maximum net return and income per rupee investment from intercropping system paves way for higher profitability (Quayyam and Ebrahim, 1988; Chattopadhyay et al., 2008). As the locally grown elephant foot yam was rich in calcium oxalate deposits,

\section{Article Info}

Accepted: 18 February 2016

Available Online: 06 March 2016

\section{Ke ywords}

Amorphophallus

$\mathrm{B}: \mathrm{C}$ ratio

Intercropping

Monetary equivalent ratio

Per day returns

Spice crops acridity free cv. Gajendra was chosen in the present investigation for the food requirements of tribal. In concern with the profitable returns under sloppy foot hills of Imphal-East, elephant foot yam was intercropped with spices viz. turmeric and ginger to study the economic viability in terms of net returns, income per rupee investment, monetary equivalent ratio and per day returns.

\section{Materials and methods}

The present investigation was carried out at horticultural research farm, department of horticulture, college of agriculture, Central Agricultural University, Imphal, Manipur, India during the year 2013. The experimental soil is of Acidic ( $\mathrm{pH}$ 5.26) and clay soil. The experiment was laid out in a Randomized Block Design with seven 
treatments and three replications. The treatments comprised of elephant foot yam sole crop $\left(\mathrm{T}_{1}\right)$, single row of turmeric planted in the inter-rows elephant foot yam $\left(T_{2}\right)$, double row of turmeric planted in the interrows elephant foot yam $\left(\mathrm{T}_{3}\right)$, single row of ginger planted in the inter-rows elephant foot yam $\left(\mathrm{T}_{4}\right)$, double row of turmeric planted in the inter-rows elephant foot yam $\left(\mathrm{T}_{5}\right)$, turmeric sole crop $\left(\mathrm{T}_{6}\right)$ and ginger sole crop $\left(\mathrm{T}_{7}\right)$. Spacing of $90 \times 90 \mathrm{~cm}$ row to row and plant to plant was adopted for elephant foot yam constantly. Turmeric/ginger rhizomes planted at a distance of $25 \mathrm{x}$ $25 \mathrm{~cm}$ row to row and plant to plant in sole cropping. Where as in single row planting, only one row of ginger/turmeric planted in the inter-rows of elephant foot yam at $25 \mathrm{~cm}$ spacing between plant to plant and in double row planting, 2 rows of turmeric/ginger planted in the inter-rows of elephant foot yam at a distance of $25 \mathrm{x}$ $25 \mathrm{~cm}$ plant to plant in rows. The number of turmeric or ginger plants present in single row (56), double row (112) and the sole crop (259) will vary accordingly. Elephant foot yam corms weighing $250 \mathrm{~g}$ and for turmeric and ginger, primary rhizomes weighing 10-20 g each was used as the planting material. Recommended cultural practices and plant protection measures were carried out regularly.

The harvested corms and rhizomes of turmeric and ginger from each net plot were weighed separately and yield per plot was obtained then converted into tonnes per hectare. Cost of cultivation was calculated by sums of fixed cost and variable costs. Net returns wereestimated by subtracting cost of cultivation from gross return. The benefit cost ratio (income per rupee investment) was calculated by dividing the net return (Rs $\mathrm{ha}^{-1}$ ) by the total cost cultivation ( $\mathrm{Rs} \mathrm{ha}^{-1}$ ). To evaluate economic superiority of intercropping systems monetary equivalent ratio and per day returns were also calculated as given by Seran and Brintha (2009).

Monetary equivalent ratio $=(\mathrm{ra}+\mathrm{rb}) / \mathrm{Ra}$

Where,

ra, rb-monetary returns from a and b; Ra-Highest sole crop monetary return,

$\mathrm{ra}=\mathrm{Pa} \times \mathrm{Ya}, \mathrm{rb}=\mathrm{Pb} \times \mathrm{Yb}$.

Where,

$\mathrm{Pa}$, Pb-Prices of unit weight of crop a and $\mathrm{b}$; $\mathrm{Ya}, \mathrm{Yb}$ Yield of $a$ and $b$

Per day returns $=$ Net returns $/$ cropping period

\section{Results and discussion}

Yield of elephant foot yam was significantly affected with the intercropping of spice crops as mentioned in the Table 1. Elephant foot yam (13.02 $\left.\mathrm{t} \mathrm{ha}^{-1}\right)$, turmeric (42.84 $\mathrm{t} \mathrm{ha}^{-1}$ ) and ginger $36.51 \mathrm{t} \mathrm{ha}^{-1}$ ) sole crops recorded superior yield. Favourable conditions and lack of interspecific competition provided significantly higher yield in sole crops in agreement with the findings of Singh et al. (2013). High rhizome yield and market price of turmeric exhibited superior gross returns $(7,28,280$ Rs $h^{-1}$ ) when grown as sole crop. On the basis of prevailing market prices of different treatments gross returns (Table 1), cost of cultivation, net returns, benefit cost ratio, monetary equivalent ratio and per day returns were calculated for each treatment and furnished below (Table 2).

\section{Gross returns}

Turmeric sole crop recorded higher gross returns (7, 28,280 Rs $\mathrm{ha}^{-1}$ ) followed by the elephant foot yam intercropped with double row of turmeric $(5,68,720 \mathrm{Rs}$ $\mathrm{ha}^{-1}$ ) and the minimum gross return was fetched from the sole crop of elephant foot yam (1, 95,300 Rs ha $\left.{ }^{-1}\right)$.

\section{Benefit cost ratio}

As well considering the data on the benefit cost ratio (Table 2), except sole crop of elephant foot yam, remaining treatments showed higher benefits. Sole crop of turmeric (8.11) and ginger (4.21) gave the income per rupee investment. Whereas among the intercropped treatments net returns (456449.45 $\left.\mathrm{Rs} \mathrm{ha}^{-1}\right)$ and income per rupee investment (4.07) was highest in elephant foot yam with double row of turmeric. Minimum amount of cost of cultivation and high yield in the sole crops of turmeric and ginger added highest economic benefits as obtained by Ehsanullah et al. (2011) and Njoku and Muoneke (2008). Despite the fact that in the present study sole crop of elephant foot yam recorded least net returns (082844.20 Rs ha ${ }^{-1}$ ) because of substandard yield $\left(13.02 \mathrm{t} \mathrm{ha}^{-1}\right)$ that lead to the lowest benefit cost ratio (0.74). These findings were in agreement with Seran and Brintha (2009), mentioned that yield and market value, plays important role than the number of crops that determine the economic returns.

\section{Monetary equivalent ratio and per day returns}

Monetary equivalent ratio defined as the sum of the ratios of intercrop monetary returns to the highest sole crop 
monetary return from the entire land area occupied by all intercrops per unit time (Adetioye and Adekunle, 1989). Among the intercropped treatments, elephant foot yam with double row of turmeric expressed maximum monetary equivalent ratio (0.78) and per day returns (2535.83 Rs ha') followed by elephant foot yam with double row of ginger. Whereas highest per day returns (3601.75 Rs ha ${ }^{-1}$ ) from sole crop of turmeric resulted from the higher yield due to more number of turmeric plants (259) over double row (112) and single row (56) of intercropping.

Table 1. Gross returns of the intercropping system.

\begin{tabular}{|c|c|c|c|c|c|c|c|}
\hline \multirow[b]{2}{*}{ Treatments } & \multirow{2}{*}{$\begin{array}{l}\text { Corm yield } \\
\left(\mathrm{t} \mathrm{ha}^{-1}\right)\end{array}$} & \multirow{2}{*}{$\begin{array}{l}\text { Intercrop } \\
\text { yield } \\
\left.(\mathbf{t ~ h a})^{-1}\right)\end{array}$} & \multicolumn{2}{|l|}{ Price $\left(\operatorname{Rs~t}^{-1}\right)$} & \multicolumn{2}{|c|}{ Returns (Rs ha $\left.{ }^{-1}\right)$} & \multirow{2}{*}{$\begin{array}{l}\text { Gross } \\
\text { returns } \\
\left(\text { Rs ha }^{-1}\right)\end{array}$} \\
\hline & & & $\begin{array}{l}\text { Elephant foot } \\
\text { yam }\end{array}$ & Intercrop & $\begin{array}{l}\text { Elephant } \\
\text { foot yam }\end{array}$ & Intercrop & \\
\hline $\mathbf{T}_{1}$ & 13.02 & - & 15000 & - & 195300 & - & 195300 \\
\hline $\mathbf{T}_{2}$ & 07.17 & 14.53 & 15000 & 17000 & 107550 & 247010 & 354560 \\
\hline $\mathbf{T}_{3}$ & 11.27 & 23.51 & 15000 & 17000 & 169050 & 399670 & 568720 \\
\hline $\mathbf{T}_{4}$ & 11.73 & 9.65 & 15000 & 15000 & 175950 & 144750 & 320700 \\
\hline $\mathbf{T}_{5}$ & 07.20 & 18.18 & 15000 & 15000 & 108000 & 272700 & 380700 \\
\hline $\mathbf{T}_{6}$ & - & 42.84 & - & 17000 & - & 728280 & 728280 \\
\hline $\mathbf{T}_{7}$ & - & 36.51 & - & 15000 & - & 547650 & 547650 \\
\hline S.Em $( \pm)$ & 0.55 & 1.25 & & & & & \\
\hline $\mathrm{CD}(0.05)$ & 1.78 & 4.08 & & & & & \\
\hline
\end{tabular}

Table 2. Economic viability of the intercropping system.

\begin{tabular}{llllll}
\hline Treatments & $\begin{array}{l}\text { Cost of cultivation } \\
\left(\text { Rs ha }^{-\mathbf{1}}\right)\end{array}$ & $\begin{array}{l}\text { Net returns } \\
\text { (Rs ha }^{-\mathbf{1}} \text { ) }\end{array}$ & $\begin{array}{l}\text { B:C } \\
\text { ratio }\end{array}$ & Monetary Equivalent Ratio & $\begin{array}{l}\text { Per Day Returns } \\
\text { (Rs ha }^{-\mathbf{1}} \text { ) }\end{array}$ \\
\hline $\mathbf{T}_{\mathbf{1}}$ & 112455.80 & 082844.20 & 0.74 & - & 460.25 \\
$\mathbf{T}_{\mathbf{2}}$ & 104863.05 & 249696.95 & 2.38 & 0.49 & 1387.21 \\
$\mathbf{T}_{\mathbf{3}}$ & 112270.55 & 456449.45 & 4.07 & 0.78 & 2535.83 \\
$\mathbf{T}_{\mathbf{4}}$ & 109307.40 & 211392.60 & 1.93 & 0.59 & 1174.40 \\
$\mathbf{T}_{\mathbf{5}}$ & 121159.40 & 259540.60 & 2.14 & 0.70 & 1441.89 \\
$\mathbf{T}_{\mathbf{6}}$ & 079964.80 & 648315.20 & 8.11 & - & 3601.75 \\
$\mathbf{T}_{\mathbf{7}}$ & 105090.80 & 442559.20 & 4.21 & - & 2458.66 \\
\hline
\end{tabular}

In the present experiment brought in elephant foot yam cv. Gajendra yield was far below than the average yield due to the adverse acidic soil conditions. Yet simultaneous growing of spice crops like ginger or turmeric not only veiled the substandard yield of elephant foot yam but also corroborated economic viability. These results are in conformity with Chattopadhyay et al. (2008) in elephant foot yam intercropping system and Ehsanullah et al. (2011) in maizemash intercropping system. With the help of above results it has been revealed that elephant foot yam cv. Gajendra intercropped with double row of turmeric would be the appropriate to harvest acridity free corms for providing nutritional security in addition to profitable returns for the development of socio-economic condition of tribal farmers under sloppy foot hills of Imphal-East.

\section{Conflict of interest statement}

Authors declare that they have no conflict of interest.

\section{References}

Adetioye, P.O., Adekunle, A.A., 1989. Concept of monetary equivalent ratio and its usefulness in the evaluation of intercropping advantages. Trop. Agric. 66, 337-341.

Chattopadhyay, A., Mukhopadhyay, S.K., Rajib, N., 2008. Short duration vegetables as intercrops in elephant foot yam in the gangetic alluvium of West Bengal: analysis of growth, yield and economics. J. Root Crops. 34(1), 10-14.

Ehsanullah, M., Javed, R., Tariq, A., 2011. Bio-economic assessment of maize-mash intercropping system. Crop Environ. 2(2), 41-46.

Njoku, D.N., Muoneke, C.O., 2008. Effect of cowpea planting density on growth, yield and productivity of component crops in cowpea/cassava intercropping system. J. Trop. Agric. Food Environ. Exten. 7(2), 106 -113.

Quayyam, M.A., Ebrahim, A.M., 1988. Productivity and profitability of cabbage intercropped with vegetables. Bangl. Horticult. 16(2), 44-46. 
Salter, P.J., 1986. An alternative method of cutting cost of production. National Vegetable Research Station, Wellesbourne UK. Grower. 105(24), 23-30.

Seran, T.H., Brintha, I., 2009. Biological and economic efficiency of radish (Raphanus sativus L.) intercropped with vegetable amaranthus (Amaranthus tricolor L.). Open Horticult. J. 2, 17-21.

Singh, R.P., Bhushan, S., Kumar, S., Shanker, R., 2013. Yield assessment of elephant foot yam grown under multilayer vegetable cropping system. Bioscan 8(4), 1237-1239.

\section{How to cite this article:}

Thirumdasu, R. K., Bijaya Devi, A.K., Thokchom, M., 2016. Corroborated economic viability of acridity free elephant foot yam introduction with spice intercropping under sloppy foot hills of Imphal-East. Int. J. Curr. Res. Biosci. Plant Biol. 3(3), 30-33.

doi: $\underline{\text { http://dx.doi.org/10.20546/ijcrbp.2016.303.006 }}$ 